\title{
Production and water yield of cauliflower under irrigation depths and nitrogen doses
}

\author{
Reginaldo M. de Oliveira ${ }^{1}$, Rubens A. de Oliveira ${ }^{1}$, Sanzio M. Vidigal ${ }^{2}$, \\ Ednaldo M. de Oliveira ${ }^{3}$, Lorença B. Guimarães ${ }^{1} \&$ Paulo R. Cecon $^{1}$
} ${ }^{1}$ Universidade Federal de Viçosa. Viçosa, MG, Brasil. E-mail: reginaldomoliveira@hotmail.com (Corresponding author) - ORCID: 0000-0002-1880-0730;
rubens@ufv.br - ORCID: 0000-0003-2557-592X; lorenca.barroso@ufv.br - ORCID: 0000-0001-7299-1024; cecon@ufv.br - ORCID: 0000-0001-8213-0199
${ }^{2}$ Empresa de Pesquisa Agropecuária de Minas Gerais/Centro Tecnológico da Zona da Mata. Viçosa, MG, Brasil. E-mail: sanziomv@epamig.br - ORCID:
0000-0003-2895-0203

${ }^{3}$ Instituto Federal do Espirito Santo. Santa Teresa, ES, Brasil. E-mail: ednaldo.oliveira@ifes.edu.br - ORCID: 0000-0002-1182-7623

\begin{abstract}
Cauliflower is a brassica produced and consumed in Brazil, whose cultivation depends on the adequate supply of water and nutrients. The objective of this study was to evaluate the effect of irrigation depths and nitrogen doses on the production components and water yield of cauliflower hybrid Barcelona CMS. The treatments consisted of five irrigation water depths $(0,75,100,125$ and $150 \%$ of the crop evapotranspiration) combined with five nitrogen doses $\left(0,75,150,300\right.$ and $\left.450 \mathrm{~kg} \mathrm{ha}^{-1}\right)$. The experiment was conducted in a completely randomized design with a split-plot arrangement. The effects of these factors were evaluated using the response surface methodology. The water yield of the crop decreases with increasing irrigation water depth; therefore, the yield is higher when water replenishment is lower than the recommended. The highest estimated total inflorescence yield is $24,547.80 \mathrm{~kg} \mathrm{ha}^{-1}$, with a inflorescence mean diameter of $19.60 \mathrm{~cm}$, a inflorescence mean height of $12.25 \mathrm{~cm}$, and an inflorescence fresh weight of $858.90 \mathrm{~g} \mathrm{plant}^{-1}$, obtained with an irrigation water depth equivalent to $132.09 \%$ of the crop evapotranspiration (ETc) and a nitrogen dose of $450 \mathrm{~kg} \mathrm{ha}^{-1}$. The highest inflorescence diameter and height are obtained with an irrigation depth equivalent to 128.70 and $108.20 \%$ of ETc, respectively, and a nitrogen dose of $450 \mathrm{~kg} \mathrm{ha}^{-1}$. Therefore, the best productivity response of the Barcelona CMS cauliflower hybrid can be obtained using an irrigation depth greater than the crop evapotranspiration, regardless of the nitrogen doses.
\end{abstract}

Key words: Brassica oleracea L., irrigation management, nitrogen fertilization

\section{Produção e produtividade da água do couve-flor sob lâminas de irrigação e doses de nitrogênio}

RESUMO: A couve-flor é uma brássica bastante produzida e consumida no Brasil, cujo cultivo é dependente do suprimento adequado de água e nutrientes. Portanto, objetivou-se com este estudo, avaliar o efeito da aplicação de lâminas de irrigação e doses de nitrogênio nos componentes de produção e na produtividade da água da cultura da couve-flor híbrida 'Barcelona CMS'. Foram avaliadas as lâminas de 0, 75, 100, 125 e 150\% da evapotranspiração da cultura combinadas com cinco doses de nitrogênio $\left(0,75,150,300\right.$ e $\left.450 \mathrm{~kg} \mathrm{ha}^{-1}\right)$. O experimento foi conduzido em delineamento inteiramente casualizado com arranjo em parcelas subdivididas. Os efeitos da desses fatores foram avaliados pela metodologia de superfície de resposta. Observou-se que a produtividade da água pela cultura apresenta relação decrescente com a lâmina de água aplicada; portanto, a produtividade é maior quando a reposição de água é menor que o recomendado. A maior produtividade total da couve-flor estimada é de $24.547,80 \mathrm{~kg} \mathrm{ha}^{-1}$, com diâmetro médio de $19,60 \mathrm{~cm}$, altura média de $12,25 \mathrm{~cm}$ e massa fresca da inflorescência de 858,90 g por planta, obtida com irrigação equivalente a $132,09 \%$ da evapotranspiração da cultura e $450 \mathrm{~kg} \mathrm{ha}^{-1}$ de nitrogênio. Para obtenção do maior diâmetro e altura de inflorescência é necessária lâminas de irrigação equivalentes a 128,70 e 108,20\% da evapotranspiração da cultura, respectivamente, na dose de $450 \mathrm{~kg} \mathrm{ha}^{-1}$ de nitrogênio. Portanto, a melhor resposta da produtividade da couve-flor híbrida ‘Barcelona CMS’ pode ser obtida com lâmina de irrigação superior à evapotranspiração da cultura, independentemente da dose de nitrogênio aplicada.

Palavras-chave: Brassica oleracea L., manejo da irrigação, adubação nitrogenada 


\section{INTRODUCTION}

Cauliflower (Brassica oleracea L. var botrytis L.) is one of the most cultivated and consumed brassicas in Brazil (Castoldi et al., 2009; Torres et al., 2015). Horticulture can provide farmers with a good economic return when crop species are cultivated considering adequate fertilization, cultural practices and water supply.

In general, fertilization of cauliflower is inadequately managed and thus, nutrients such as phosphorus, nitrogen and potassium are applied in larger quantities, increasing production costs (Oliveira et al., 2005).

Cauliflower is a short-cycle crop specie; therefore, it has high demand for nitrogen, that has a structural function in the plant; participates in the processes of ionic absorption, photosynthesis, respiration, and cell multiplication and differentiation (Kano et al., 2010); and it is fundamental for rapid and vigorous vegetative development of cauliflower. Nitrogen directly influences inflorescence growth (May et al., 2007). Increases in productivity response to nitrogen fertilization have been reported by several authors (Camargo et al., 2009; Kano et al., 2010).

In addition, adequate water replenishment in vegetable species for cultivation, such as cauliflower, can directly affect the quantity and quality of production (Tomassoni et al., 2013; Tangune et al., 2016). Inexistence of irrigation management is common in irrigated vegetable production areas, which generates a wastage of water in addition to energy and socioenvironmental problems. Proper irrigation management practices contribute to increases in productivity, improving the quality of agricultural products, and preserving water resources.

Considering the importance of cauliflower crops and the lack of information about their water and nutritional requirements, the objective of the present study was to evaluate the effect of different irrigation depths and nitrogen dose on the production of the cauliflower hybrid 'Barcelona CMS'.

\section{Material ANd Methods}

The research was conducted in the experimental area of the irrigation and drainage at the Departamento de Engenharia Agrícola da Universidade Federal de Viçosa (DEA/UFV), Viçosa, MG State, Brazil $\left(20^{\circ} 45^{\prime} \mathrm{S}, 42^{\circ} 51^{\prime} \mathrm{W}\right.$, at altitude of $651 \mathrm{~m})$.

The soil in the area was classified as an Oxisol with sandyclay texture, specific mass of $1.1 \mathrm{~kg} \mathrm{dm}^{-3}$, field capacity of $0.326 \mathrm{~m}^{3} \mathrm{~m}^{-3}$, and a wilting point of $0.208 \mathrm{~m}^{3} \mathrm{~m}^{-3}$. The soil chemical analysis showed $2.71 \mathrm{dag} \mathrm{kg}^{-1}$ of organic matter, $\mathrm{pH}$ in water of $5.70,23.46 \mathrm{mg} \mathrm{dm}^{-3}$ of $\mathrm{P}, 106.80 \mathrm{mg} \mathrm{dm}^{-3}$ of $\mathrm{K}$, $3.26 \mathrm{cmol}_{c} \mathrm{dm}^{-3}$ of $\mathrm{Ca}^{2+}, 0.71 \mathrm{cmol}_{\mathrm{c}} \mathrm{dm}^{-3}$ of $\mathrm{Mg}^{2+}, 0 \mathrm{cmol}_{\mathrm{c}} \mathrm{dm}^{-3}$ of $\mathrm{Al}, 3.48 \mathrm{cmol} \mathrm{dm}^{-3}$ of $\mathrm{H}+\mathrm{Al}, \mathrm{CEC}$ of $7.72 \mathrm{cmol} \mathrm{dm}_{\mathrm{c}}^{-3}$, and a base saturation of $54.82 \%$, according to methodologies described by EMBRAPA (2017).

Seedlings of a cauliflower hybrid 'Barcelona CMS' 38 days after sowing (DAS), produced in 200-cell plastic trays, were transplanted on August 14, 2014. The spacing used was $0.70 \mathrm{~m}$ between planting rows and $0.50 \mathrm{~m}$ between plants, corresponding to 28.570 plants ha $^{-1}$. Each experimental unit consisted of 24 plants distributed in three parallel rows with eight plants each, resulting in a total area of $8.40 \mathrm{~m}^{2}$, and an experimental area of $2.10 \mathrm{~m}^{2}$. The six central plants were used in the evaluations.

The experiment was conducted in a completely randomized design with a split-plot arrangement; the plots consisted of five irrigation water depth treatments based on the crop evapotranspiration $\left(\mathrm{ET}_{\mathrm{c}}\right)\left(\mathrm{L}_{0}=0 \% \mathrm{ET}_{\mathrm{c}} ; \mathrm{L}_{1}=75 \% \mathrm{ET}_{\mathrm{c}} ; \mathrm{L}_{2}=\right.$ $100 \% \mathrm{ET}_{\mathrm{c}} ; \mathrm{L}_{3}=125 \% \mathrm{ET}_{\mathrm{c}}$; and $\left.\mathrm{L}_{4}=150 \% \mathrm{ET}_{\mathrm{c}}\right)$; and the subplots consisted of five nitrogen doses $\left(\mathrm{N}_{0}=0 \mathrm{~kg} \mathrm{ha}^{-1} ; \mathrm{N}_{1}=75 \mathrm{~kg} \mathrm{ha}^{-1}\right.$; $\mathrm{N}_{2}=150 \mathrm{~kg} \mathrm{ha}^{-1} ; \mathrm{N}_{3}=300 \mathrm{~kg} \mathrm{ha}^{-1}$; and $\mathrm{N}_{4}=450 \mathrm{~kg} \mathrm{ha}^{-1}$ ).

The recommended fertilization dose was obtained based on soil analysis and by following the recommendation of fertilizer use for the State of Minas Gerais, Brazil - $5^{\text {th }}$ Approximation (CFSEMG, 1999). Thus, fertilization at planting was carried out using $300 \mathrm{~kg} \mathrm{ha}^{-1}$ of $\mathrm{P}_{2} \mathrm{O}_{5}, 20 \mathrm{~kg} \mathrm{ha}^{-1}$ of borax, $20 \mathrm{~kg} \mathrm{ha}^{-1}$ of zinc sulfate, and $80 \mathrm{~kg} \mathrm{ha}^{-1}$ of $\mathrm{K}_{2} \mathrm{O}$; this measure of potassium is $25 \%$ of the recommended amount, and the other quantities were applied together with the nitrogen topdressing.

The nitrogen topdressing was applied to all plots using urea ( $45 \%$ of $N$ ), according to the evaluated doses, and was divided into three applications. The first application (20\% of the dose) was carried out 15 days after transplanting (DAT), the second $(40 \%)$ at $30 \mathrm{DAT}$, and the last (40\%) at 45 DAT. The fertilizers were diluted in $7.20 \mathrm{~L}$ of water, and $300 \mathrm{~mL}$ was applied near each plant. Also, fertilization with molybdenum in the form of sodium molybdate at the concentration of $1 \mathrm{~g} \mathrm{~L}^{-1}$, was applied by spraying at 15 and 30 DAT (Vidigal et al., 2007).

The irrigation was carried out using a drip irrigation system, with a mean flow of $2.24 \mathrm{~L} \mathrm{~h}^{-1}$ per dripper, a service pressure of $140 \mathrm{kPa}$, and a Christiansen Uniformity Coefficient (CUC) of $94.50 \%$. The pressure-compensating drippers were spaced $0.50 \mathrm{~m}$ apart, and each line was positioned close to the plant row at $0.70 \mathrm{~m}$, providing an application intensity of $6.40 \mathrm{~mm} \mathrm{~h}^{-1}$, with daily irrigation frequency.

The same irrigation water depths, corresponding to $100 \%$ of $\mathrm{ET}_{\mathrm{c}}$, were applied in all treatments during the first 12 days. The program REF-ET (Allen, 2000) was used to calculate the estimated reference evapotranspiration $\left(\mathrm{ET}_{0}\right)$. Subsequently, the $\mathrm{ET}_{0}$ was used to calculate the $\mathrm{ET}_{c}$. The water demand was estimated according to the water balance, in which the water output was estimated by the ET $\mathrm{E}_{c}$ and the water inputs were represented by irrigation depths and precipitation events, using coefficients of adjustment in relation to the $\mathrm{ET}_{0}$ to calculate the irrigation water depth. The crop evapotranspiration was estimated using Eq. 1 (Mantovani et al., 2009):

$$
\mathrm{ET}_{\mathrm{c}}=\mathrm{ET}_{0} \mathrm{~K}_{\mathrm{c}} \mathrm{K}_{\mathrm{L}} \mathrm{K}_{\mathrm{s}}
$$

where:

$\mathrm{ET}_{c}$ - crop evapotranspiration $\left(\mathrm{mm} \mathrm{d}^{-1}\right)$;

$\mathrm{ET}_{0}$ - reference evapotranspiration $\left(\mathrm{mm} \mathrm{d}^{-1}\right)$;

$\mathrm{K}_{\mathrm{c}} \quad$ - crop coefficient, dimensionless;

$\mathrm{K}_{\mathrm{L}}$ - location coefficient, dimensionless; and,

$\mathrm{K}_{\mathrm{s}} \quad$ - stress coefficient, dimensionless.

The plants were irrigated daily, assuming the value of Ks equal to 1.0. The $\mathrm{K}_{\mathrm{L}}$ value was determined by Eq. 2 (Mantovani et al., 2009): 


$$
\mathrm{K}_{\mathrm{L}}=0.1 \sqrt{\mathrm{P}}
$$

where:

$\mathrm{P}$ - percentage value of wet or shaded area, whichever is greater.

For the initial stage of crop growth, $20 \%$ of the wet area was considered. The shaded area was measured daily, and when it became larger than the wet area, its value was used. $\mathrm{K}_{c}$ values for initial, vegetative, flowering, and maturation stages of 0.45 , $0.80,1.05$ and 0.90 , respectively, were used for the calculations (Doorenbos \& Kassam, 1979).

Harvesting was carried out when the cauliflower plants were firm and compact, at $71 \mathrm{DAT}$; six central plants of each treatment were harvested by cutting close to the ground. Subsequently, the stem, leaves and inflorescence of each plant were separated individually. Fresh weight, number of leaves, and diameter and height of the inflorescence were determined; the dry weight of each part of the plant was obtained by drying in an oven at $65^{\circ} \mathrm{C}$ in subsamples of approximately $200 \mathrm{~g}$.

The water yield (WY) $\left(\mathrm{kg} \mathrm{m}^{-3}\right)$ was determined by the ratio between the inflorescence yield per unit area $\left(\mathrm{kg} \mathrm{ha}^{-1}\right)$ and the volume of water applied per unit area $\left(\mathrm{m}^{-3} \mathrm{ha}^{-1}\right)$ during the crop cycle. The total water yield (TWY) was determined as a function of the water from irrigation and precipitation, and the irrigation water yield (IWY) was determined as a function of only the irrigation depth.

The data were submitted to the response surface methodology. The models were chosen based on the significance of the regression coefficients using the t test, at $\mathrm{p} \leq 0.05$, on the coefficient of determination $\left(\mathrm{R}^{2}\right)$ and on the behavior of phenomenon being studied.

\section{Results AND Discussion}

Table 1 shows the total irrigation water depths applied to each treatment and the total precipitation events in the experimental period.

The number of irrigations applied were 11 (crop stage I), 31 (stage II) and 28 (stage III), totaling 70 irrigation events.
Table 2 shows the regression equations adjusted to the production components of the Barcelona CMS cauliflower, in which the crop presented quadratic response to the irrigation depths and linear response to the nitrogen doses.

Figure 1 shows the response surface of the inflorescence diameter (ID) (Figure 1A) and inflorescence height (IH)

$$
\hat{\mathrm{Y}}=11.1923+0.1287^{*} \times \mathrm{L}-0.0005^{*} \times \mathrm{L}^{2}+0.0004 \times \mathrm{D}
$$

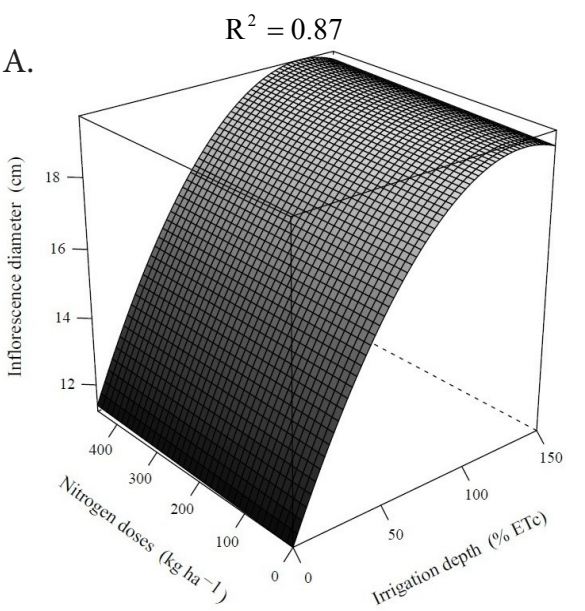

$\hat{\mathrm{Y}}=8.1596+0.0649^{*} \times \mathrm{L}-0.0003^{*} \times \mathrm{L}^{2}+0.0017^{*} \times \mathrm{D}$

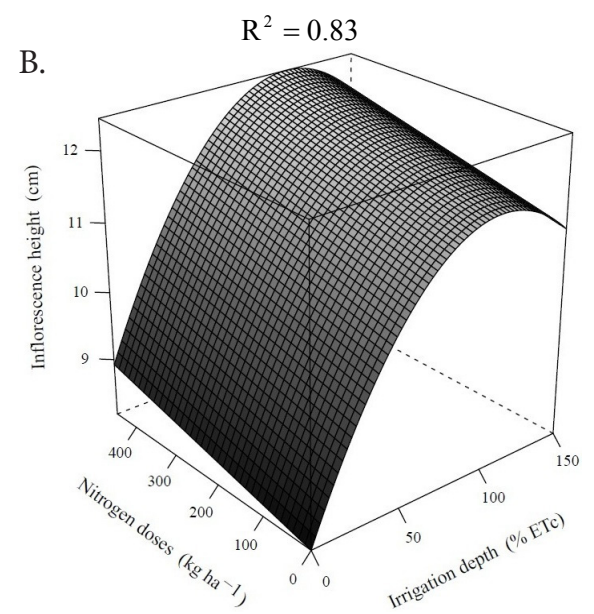

${ }^{*}$ Significant at $\mathrm{p} \leq 0.05$ by $\mathrm{F}$ test

Figure 1. Response surface for inflorescence diameter - ID (A) and inflorescence height - IH (B), in centimeters, as a function of irrigation depth (L) and nitrogen doses (D)

\begin{tabular}{|c|c|c|c|c|c|c|}
\hline \multirow{2}{*}{ Crop stage } & \multicolumn{5}{|c|}{ Total irrigation water depth $(\mathrm{mm})$} & \multirow{2}{*}{$\begin{array}{l}\text { Precipitation } \\
(\mathrm{mm})\end{array}$} \\
\hline & $0 \% \mathbf{E T}_{\mathrm{c}}$ & $75 \% \mathrm{ET}_{6}$ & $100 \% \mathrm{ET}_{\mathrm{c}}$ & $125 \% \mathrm{ET}_{\mathrm{c}}$ & $150 \% \mathrm{ET}_{\mathrm{c}}$ & \\
\hline I & 8.63 & 8.63 & 8.63 & 8.63 & 8.63 & 2.40 \\
\hline II & - & 60.94 & 81.25 & 101.56 & 121.87 & 21.20 \\
\hline III & - & 123.81 & 165.08 & 206.35 & 247.62 & 35.40 \\
\hline Total & 8.63 & 193.38 & 254.96 & 316.54 & 378.12 & 59.00 \\
\hline
\end{tabular}

Table 1. Total irrigation water depths applied and precipitation during the crop stages

$\mathrm{ET}_{\mathrm{c}}$ - Crop evapotranspiration

Table 2. Coefficients of regression equations adjusted as a function of irrigation water depths (L) and nitrogen doses (D) for inflorescence diameter (ID), inflorescence height (IH), inflorescence fresh weight (IFW), total inflorescence yield (TIY), total water yield (TWY) and irrigation water yield (IWY), according to the model $\mathrm{Y}=\beta_{0}+\beta_{1} \mathrm{~L}+\beta_{2} \mathrm{~L}^{2}+\beta_{3} \mathrm{D}$ and the respective significances

\begin{tabular}{crrrrrrr}
\hline $\mathbf{Y}$ & \multicolumn{1}{c}{$\boldsymbol{\beta}_{0}$} & $\boldsymbol{\beta}_{1}$ & $\boldsymbol{p}$ value & $\boldsymbol{\beta}_{2}$ & $\boldsymbol{p}$ value & $\boldsymbol{\beta}_{3}$ & $\boldsymbol{p}_{\text {value }}$ \\
ID & 11.1923 & 0.1287 & 0.01 & -0.0005 & 0.01 & 0.0004 & 0.38 \\
IH & 8.1596 & 0.0649 & 0.01 & -0.0003 & 0.01 & 0.0017 & 0.05 \\
IFW & 219.6933 & 9.6653 & 0.01 & -0.0365 & 0.01 & 0.0025 & 0.05 \\
TIY & 6276.9523 & 276.1514 & 0.01 & -1.0428 & 0.01 & 0.0717 & 0.05 \\
TWY & 11.0013 & -0.0358 & 0.01 & - & - & 0.0020 & 0.15 \\
IWY & 87.7058 & -1.3698 & 0.01 & 0.0056 & 0.01 & -0.0032 & 0.35 \\
\hline
\end{tabular}


(Figure 1B) of cauliflower as a function of irrigation depths and nitrogen doses. The critical irrigation depths that allowed the estimation of maximum values of ID $(19.65 \mathrm{~cm})$ and $\mathrm{IH}$ $(12.43 \mathrm{~cm})$ were 128.70 and $108.20 \%$ of $\mathrm{ET}_{\mathrm{c}}$, respectively, considering the application of $450 \mathrm{~kg} \mathrm{ha}^{-1}$ of $\mathrm{N}$.

These results indicate a positive relationship between the cauliflower ID and IH with water depth and nitrogen doses, considering the increase of its respective values.

Monteiro et al. (2010) evaluated several cauliflower hybrids in Jaboticabal, SP State, Brazil, and found ID ranging from 23.55 to $26.37 \mathrm{~cm}$ and $\mathrm{IH}$ from 10.03 to $12.84 \mathrm{~cm}$. Contrastingly, Morais Júnior et al. (2012) found IH from 11.99 to $14.10 \mathrm{~cm}$ and ID from 18.60 to $21.91 \mathrm{~cm}$ in a study in Ipameri, GO State, Brazil. These differences can be justified by the climate diversity between experimental regions, growing seasons, combinations of treatments, and genetic differences among the varieties being studied.

Figure 2 shows the response surface of total inflorescence yield (TIY) (Figure 2A) and inflorescence fresh weight (IFW) (Figure 2B) of cauliflower as a function of irrigation depths and nitrogen doses. Based on the adjusted model, the critical irrigation depth that promotes the highest TIY and IFW within each nitrogen doses is $132.09 \%$ of $\mathrm{ET}_{\mathrm{c}}$. The IFW obtained under

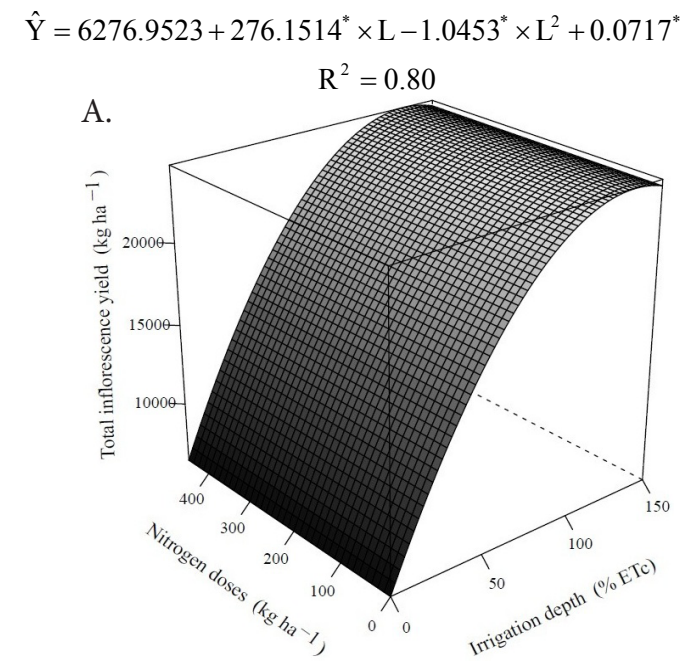

$\hat{\mathrm{Y}}=219.6933+9.6653^{*} \times \mathrm{L}-0.0365^{*} \times \mathrm{L}^{2}+0.0025^{*} \times \mathrm{D}$

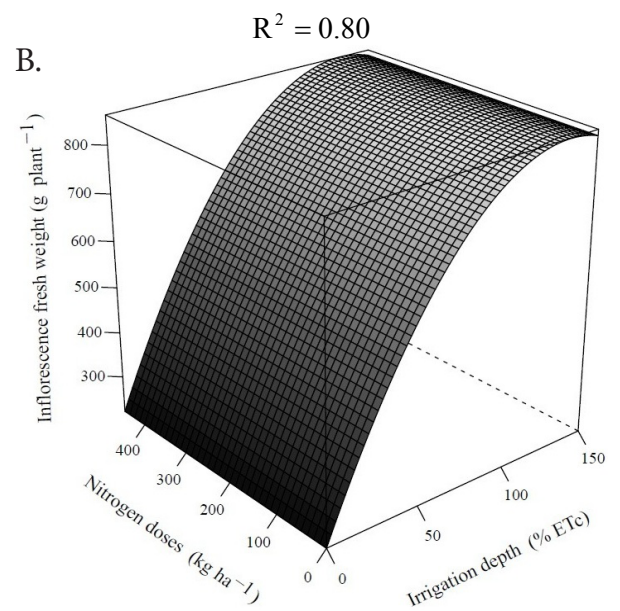

*Significant at $\mathrm{p} \leq 0.05$ by $\mathrm{F}$ test

Figure 2. Response surface for total inflorescence yield - TIY (A) and inflorescence fresh weight - IFW (B) as a function of irrigation depth (L) and nitrogen doses (D) these conditions was $860.54 \mathrm{~g}$, which was a similar result to those found by Zanuzo et al. (2013) in several cultivars.

Considering the irrigation depth of $132.09 \%$ ET with the $\mathrm{N}$ dose of 0 , the mean estimated TIY was $24,515.64 \mathrm{~kg} \mathrm{ha}^{-1}$. The TIY increased by only $32.26 \mathrm{~kg}$ when considering the $\mathrm{N}$ dose of $450 \mathrm{~kg} \mathrm{ha}^{-1}$, indicating that nitrogen availability was not a limiting factor in production under the experimental conditions and that the use of nitrogen fertilizer under similar conditions results in small yield gains when compared to use of irrigation. Camargo et al. (2009) found a cauliflower yield of $18,780.00 \mathrm{~kg} \mathrm{ha}^{-1}$ and reported it as satisfactory, whereas Pizetta et al. (2005) found a yield of $29,600.00 \mathrm{~kg} \mathrm{ha}^{-1}$, evaluating different boron rates in sandy soils.

Figure 3 shows the response surface adjusted for TWY and IWY as well as the adjusted equations and respective determination coefficients.

Considering the water depth, there is a negative relationship between total water yield and irrigation water depth, and a positive relationship between total water yield and nitrogen dose (Figure 3A). This was not found when evaluating only the water depth applied by the irrigation system (Figure $3 \mathrm{~B}$ ). This is the most used, since it presents the costs involved with irrigation. The highest total water yield (TWY) and irrigation

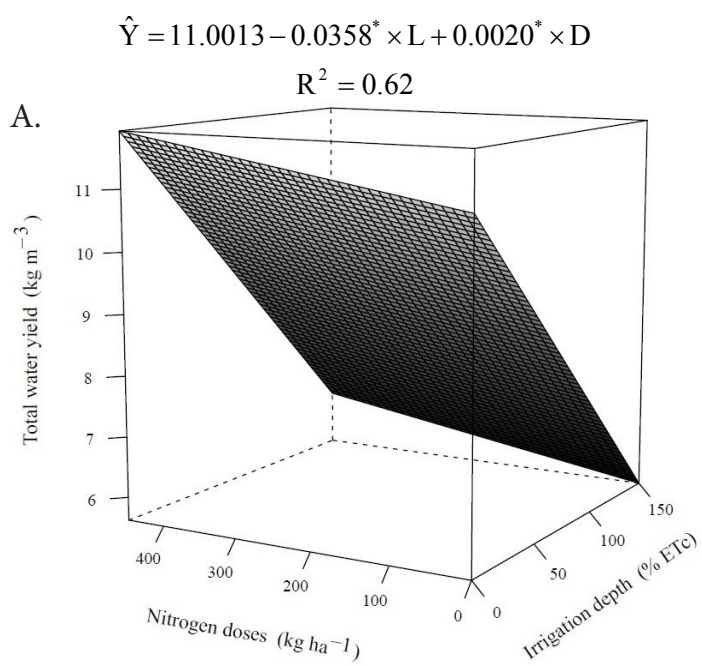

$\hat{\mathrm{Y}}=87.7058-1.3698^{*} \times \mathrm{L}+0.0056^{*} \times \mathrm{L}^{2}+0.0032^{*} \times \mathrm{D}$

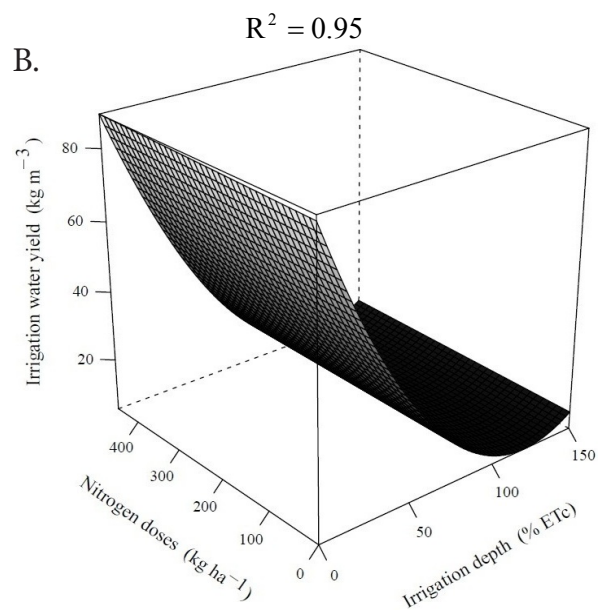

*Significant at $\mathrm{p} \leq 0.05$ by $\mathrm{F}$ test

Figure 3. Response surface for total water yield - TWY (A) and irrigation water yield - IWY (B) as a function of irrigation depth (L) and nitrogen doses (D) 
water yield (IWY) found were 11.90 and $89.15 \mathrm{~kg} \mathrm{~m}^{-3}$, respectively, with the lowest water depth and the highest nitrogen doses. According to Oliveira et al. (2012), well-nourished plants have lower water requirements.

Water use efficiency decreased with increasing irrigation water depth. This was also observed by Barros et al. (2002) when evaluating the economic yield of melon under different water depths and nitrogen fertilization doses. Similarly, Santana et al. (2009) reinforce that an increase in the irrigation depth tends to decrease water use efficiency.

Cauliflower crops have greater water use efficiency (WUE) compared to other species, such as watermelon with WUE of $24.39 \mathrm{~kg} \mathrm{~m}^{-3}$ (Morais et al., 2008) and $33.34 \mathrm{~kg} \mathrm{~m}^{-3}$ (Oliveira et al., 2012), lettuce (14.11 $\mathrm{kg} \mathrm{m}^{-3}$ ) (Silva \& Queiroz, 2013), and tomato $\left(62.72 \mathrm{~kg} \mathrm{~m}^{-3}\right.$ ) (Silva et al., 2013). Oliveira et al. (2012) emphasize that the economy of water resources is very important, especially in crops that have greater water use efficiency.

\section{Conclusion}

Variations in irrigation water depths have greater effect on the yield of the 'Barcelona CMS' cauliflower than the variation in nitrogen fertilization doses. Higher yields can be obtained with an irrigation depth of $132.09 \%$ of the crop evapotranspiration $\left(\mathrm{ET}_{\mathrm{c}}\right)$.

\section{Literature Cited}

Allen, R. G. REF-ET: Reference evapotranspiration calculation software for FAO and ASCE standardized equations - version 2.0. Idaho: Idaho University, 2000. 82p.

Barros, V. da S.; Costa, R. N. T.; Aguiar, J. V. de. Função de produção da cultura do melão para níveis de água e adubação nitrogenada no vale do Curu - CE. Irriga, v.7, p.98-105, 2002. https://doi. org/10.15809/irriga.2002v7n2p98-105

Camargo, M. S. de; Mello, S. de C.; Foltrán, D. E.; Carmello, Q. A. de C. Produtividade e podridão parda em couve-flor 'Sharon' influenciadas pela aplicação de nitrogênio e boro. Horticultura Brasileira, v.27, p.30-34, 2009. https://doi.org/10.1590/S010205362009000100006

Castoldi, R.; Charlo, H. C. de O.; Vargas, P. F.; Braz, L. T. Crescimento, acúmulo de nutrientes e produtividade da cultura da couveflor. Horticultura Brasileira, v.27, p.438-446, 2009. https://doi. org/10.1590/S0102-05362009000400007

CFSEMG - Comissão de Fertilidade do Solo do Estado de Minas Gerais. Recomendação para o uso de corretivos e fertilizantes em Minas Gerais: Quinta aproximação. Viçosa: CFSEMG, 1999. 359p.

Doorenbos, J.; Kassam, A. H. Yield response to water. Rome: Food and Agriculture Organization of the United Nations, 1979. 201p.

EMBRAPA - Empresa Brasileira de Pesquisa Agropecuária. Manual de métodos de análise de solo. 3.ed. rev. ampl. Brasília: Embrapa Informação Tecnológica, 2017. 573p.

Kano, C.; Salata, A. C.; Higuti, A. R. O.; Godoy, A. R.; Cardoso, A. I. I.; Evangelista, R. M. Produção e qualidade de couve-flor cultivar Teresópolis Gigante em função de doses de nitrogênio. Horticultura Brasileira, v.28, p.453-457, 2010. https://doi. org/10.1590/S0102-05362010000400013

Mantovani, E. C.; Bernardo, S.; Palaretti, L. F. Irrigação: Princípios e métodos. 3.ed. Viçosa: Editora UFV, 2009. 355p.
May, A.; Tivelli, S. W.; Vargas, P. F.; Samra, A. G.; Sacconi, L. V.; Pinheiro, M. Q. A cultura da couve-flor. Campinas: Instituto Agronômico de Campinas, 2007. 43p. Boletim Técnico, 200

Monteiro, B. C. B. de A.; Charlo, H. C. de O.; Braz, L. T. Desempenho de híbridos de couve-flor de verão em Jaboticabal. Horticultura Brasileira, v.28, p.115-119, 2010. https://doi.org/10.1590/S010205362010000100022

Morais, N. B. de; Bezerra, F. M. L.; Medeiros, J. F. de; Chaves, S. W. P. Resposta de plantas de melancia cultivadas sob diferentes níveis de água e de nitrogênio. Revista Ciência Agronômica, v.39, p.369-377, 2008.

Morais Júnior, O. P. de; Cardoso, A. F.; Leão, É. F.; Peixoto, N. Desempenho de cultivares de couve-flor de verão em Ipameri. Ciência Rural, v.42, p.1923-1928, 2012. https://doi.org/10.1590/ S0103-84782012005000085

Oliveira, F. L. de; Ribas, R. G. T.; Junqueira, R. M.; Padovan, M. P.; Guerra, J. G. M.; Almeida, D. L. de; Ribeiro, R. de L. D. Desempenho do consórcio entre repolho e rabanete com pré-cultivo de crotalária, sob manejo orgânico. Horticultura Brasileira, v.23, p.184-188, 2005. https://doi.org/10.1590/S0102-05362005000200004

Oliveira, P. G. F. de; Moreira, O. da C.; Branco, L. M. C.; Costa, R. N. T.; Dias, C. N. Eficiência de uso dos fatores de produção água e potássio na cultura da melancia irrigada com água de reúso. Revista Brasileira de Engenharia Agrícola e Ambiental, v.16, p.153158, 2012. https://doi.org/10.1590/S1415-43662012000200004

Pizetta, L. C.; Ferreira, M. E.; Cruz, M. C. P. da; Barbosa, J. C. Resposta de brócolis, couve-flor e repolho à adubação com boro em solo arenoso. Horticultura Brasileira, v.23, p.51-56, 2005. https://doi. org/10.1590/S0102-05362005000100011

Santana, M. J. de; Vieira, T. A.; Barreto, A. C. Efeitos dos níveis de reposição de água no solo na produtividade do tomateiro. Horticultura Brasileira, v.27, p.1378-1384, 2009.

Silva, J. M. da; Ferreira, R. S.; Melo, A. S. de; Suassuna, J. F.; Dutra, A. F.; Gomes, J. P. Cultivo do tomateiro em ambiente protegido sob diferentes taxas de reposição da evapotranspiração. Revista Brasileira de Engenharia Agrícola e Ambiental, v.17, p.40-46, 2013. https://doi.org/10.1590/S1415-43662013000100006

Silva, V. D. da; Queiroz, S. O. P. Manejo de água para produção de alface em ambiente protegido. Irriga, v.18, p.184-199, 2013. https://doi.org/10.15809/irriga.2013v18n1p184

Tangune, B. F.; Pereira, G. M.; Sousa, R. J. de; Gatto, R. F. Produção de brócolis irrigado por gotejamento, sob diferentes tensões de água no solo. Semina: Ciências Agrárias, v.37, p.7-16, 2016.

Tomassoni, F.; Santos, R. F.; Rocha, A. A. da; Galdino, T. S.; Nadaleti, W. C.; Rossi, E. de; Carpinski, M. Sensibilidade da couve-flor ao excesso de água no solo. Acta Iguazu, v.2, p.1-6, 2013.

Torres, J. L. R.; Araújo, A. S.; Barreto, A. C.; Silva Neto, O. F.; Silva, V. R.; Vieira, D. M. S. Desenvolvimento e produtividade de couve-flor e repolho influenciados por tipos de cobertura do solo. Horticultura Brasileira, v.33, p.510-514, 2010. https://doi. org/10.1590/S0102-053620150000400017

Vidigal, S. M.; Pereira, P. R. G. Couve-flor. In: Venzon, M.; Paula Júnior, T. J. de. 101 culturas: Manual de tecnologias agrícolas. Belo Horizonte: EPAMIG, 2007. Cap.36, p.301-304.

Zanuzo, M. R.; Ribeiro, L. M.; Lange, A.; Machado, R. A. F.; Massaroto, J. A. Desempenho agronômico de genótipos de couve-flor nas condições edafoclimáticas de Sinop. Horticultura Brasileira, v.31, p.332-337, 2013. https://doi.org/10.1590/S010205362013000200026 